\title{
Anti-Nociceptive and Anti-Inflammatory Activities of Methanol Leaves Extract of Ocimum Gratissimum in Mice and Rats
}

\author{
${ }^{1}$ Tanko, Y., ${ }^{2}$ Yaro, A.H., ${ }^{1}$ Mohammed K.A and ${ }^{1}$ Mohammed, A. \\ ${ }^{1}$ Department of Human Physiology, Ahmadu Bello University, Zaria, Nigeria \\ ${ }^{2}$ Department of Pharmacology, Bayero University Kano, Nigeria
}

\begin{abstract}
The methanol leaves extract of Ocimum gratissimum was investigated for possible anti-nociceptive and anti-inflammatory effects in mice and rats. Acetic acid-induced writhing (in mice) and formalin tests (in rats) were used to study the extract effects on nociception and inflammation. The extract caused a significant decrease $(P<0.05)$, which was not dose dependent inhibition on acetic acid-induced writhing and the neurogenic pain induced by formalin. The extract at the doses $(50,100$ and $200 \mathrm{mg} / \mathrm{kg})$ tested showed 75,66 and $75 \%$ inhibition of abdominal constriction in mice respectively. The highest activity resides more at the lowest dose of $50 \mathrm{mg} / \mathrm{kg}$ on the acetic acid induced abdominal constrictions. The intraperitoneal $L D_{50}$ value of the extract was found to be $1264.9 \mathrm{mg} / \mathrm{kg}$ body weight in mice. Preliminary phytochemical screening reveals the presence of alkaloids, saponins, tannins and flavonoids. The results suggest the extract contains pharmacologically active principles, and are in agreement with the local application of the plant in painful and inflammatory conditions.
\end{abstract}

Keywords: Ocimum gratissimum, anti-nociceptive, anti-inflammatory.methanol

\section{Introduction}

Ocimum gratissimum is commonly known as fever leaf in general but is has different native names in different part of the country. Ocimum gratissimum (Linn) family Labiaceae is a haberceous plant commonly found in tropical Asia especially India. The plant is also found in West Africa. In Nigeria it is found in the savannah and coastal areas. .In Yoruba language, it is known as Ewfirin ajase, Nchu-nwu in Ibo, Bunsuru daji in Hausa, Ireru in Ebira, Ebaubokho in Benin, ufuo-yibo in Urhobo and in Efik [1]. It is used in the treatment of epilepsy in the coastal area of Nigeria [2], High fever [3], and Diarrhoea [4]

This research was aimed at investigating the possible anti-nociceptive and anti-inflammatory activities of methanol leaves extract of the plant in order to support or repute the claims by traditional herbalists.

\section{Materials and Methods}

\subsection{Location of Study}

This research was carried out in the Department of Human Physiology Faculty of Medicine, Ahmadu Bello University, Zaria. Nigeria

\subsection{Drugs}

All chemicals and drugs used were obtained commercially and of analytical grade.

\subsection{Collection of Plant Material}

Fresh leaves of Ocimum gratissimum were collected from Ahmadu Bello University Main campus Zaria in the month January 2007. The plant was identified by Mallam M. Musa at the herbarium unit of Biological Science Department A.B.U., Zaria where a voucher specimen (No. 2637) has been deposited.

\subsection{Extraction of Plant Material}

The fresh leaves collected were dried under the shade and ground into powder. The powder $(100 \mathrm{~g})$ was boiled in $500 \mathrm{ml}$ of methanol for $72 \mathrm{~h}$ using a Soxhlet extractor apparatus. The solvent was evaporated on a water bath to give an average yield of $12.63 \%$.w/w. The extract was then stored in a desiccators. Solutions of the extract were prepared freshly for each study.

\subsection{Animal Management}

Adult Wistar rats of both sexes weighing between 150-200g and adult Swiss albino mice of both sexes weighing between $25-30 \mathrm{~g}$ were used for the experiments. The animals were obtained from animal house of Department of Veterinary Medicine, Ahmadu Bello University, Zaria .They were kept in well ventilated room and fed with standard grower mash. Excel feeds Plc, Kaduna and allowed water ad libitum. This research was carried out in Ahmadu Bello University in accordance with the rules governing the use of laboratory animals as 
accepted internationally.

\subsection{Acute toxicity study:}

\section{Experimental Procedures:}

This was conducted by using the method described by [5]. In the initial phase, mice were divided into 3 groups of three and treated with the methanol leaves extract of the plant at doses of 10,100 and $1000 \mathrm{mg}$ extract/ $\mathrm{kg}$ body weight intraperitoneally (i.p.) and were then observed for 24 hours for signs of toxicity including death .In the final phase, mice were divided into 4 groups of one mouse each and treated with the ethanol extract at doses of 600, 1000, 1600 and $2900 \mathrm{mg} / \mathrm{kg}$ body weight i.p. The median lethal dose $\left(\mathrm{LD}_{50}\right)$ was calculated from the second phase.

\subsection{Phytochemical Screening:}

The aqueous extract obtained was subjected to preliminary phytochemical screening, to identify the chemical constituents. The standard methods of analysis were employed [6, 7].

\subsubsection{Preliminary test for Alkaloids}

About $0.5 \mathrm{~g}$ of extract was stirred with $5 \mathrm{ml}$ of $1 \%$ extract $\mathrm{HCl}$ on water bath and filtered. The filtrate about $3 \mathrm{ml}$ was taken and divided equally into 3 portions in test tubes. In the first test tube, Dragendorff's reagent was added and occurrence of orange-red precipitate was taken as positive. To the second test tube, $1 \mathrm{ml}$ of Mayer's reagent was added and appearance of buff colour precipitate was an indication of alkaloids and the last test tube to $1 \mathrm{ml}$ of the extract a few drops of Wagner's reagent was added. A dark- brown precipitate indicates the presence of alkaloids [7].

\subsubsection{Confirmatory test for Alkaloids}

A confirmatory test designed to eliminate non-alkaloidal compounds capable of eliciting false positive reaction was carried out for the extract which gave a preliminary positive test for alkaloids. $1 \mathrm{~g}$ of extract was treated with $40 \%$ calcium hydroxide until the extract was distinctly alkaline with litmus paper and extracted twice with $10 \mathrm{ml}$ portion of chloroform. The chloroform extract were then combined and concentrated at reduced pressure to about $5 \mathrm{ml}$. This was then spotted on TLC plates and developed using four solvents of different polarities. The presence of alkaloids in the developed chromatograms was detected by spraying with freshly prepared Dragendorf's spray reagent. A positive reaction was indicated by the appearance of an orange or dark-coloured spot against a pale yellow background on the chromatograms and was confirmed as evidence that extract contain alkaloid [4].

\subsubsection{Test for flavonoids Shinoda's Test}

About $0.5 \mathrm{~g}$ of each extract was dissolved in ethanol, warmed and then filtered. Three pieces of magnesium chips was added to the filtrate followed by few drops of concentrated HCL. A pink orange or red to purple colouration was an evidence for the presence of flavonoids [8].

\subsubsection{Test for Saponins glycosides}

About $1 \mathrm{~g}$ of the extract was boiled with $5 \mathrm{ml}$ of distilled water, filtered and the filtrate divided into 2 portions. To the first portion, about $3 \mathrm{ml}$ of distilled water was added and then shaken for about 5 minutes. Frothing which persist on warming was an indication of presence of saponins. To the second portion, $2.5 \mathrm{ml}$ of the mixture of equal volume of Fehling's solutions A and B was added. A brick-red precipitate was taken as the presence of saponin glycosides $[9,4]$.

\subsubsection{Test for Steroidal Glycosides (Liebermann-Burkhart Test) \\ (i) Steroidal nucleus}

About $0.5 \mathrm{~g}$ of the extract was dissolved in $2 \mathrm{ml}$ of acetic anhydrite and cooled in the ice then concentrated tetraoxosulphate (IV) acid $\left(\mathrm{H}_{2} \mathrm{SO}_{4}\right)$ was carefully added. Thus, development of colour from violent to bluish-green indicates the presence of a steroidal ring of the glycosides [10].

\section{(ii ) Terpenoids}

About $0.5 \mathrm{~g}$ of the extract was dissolved in ethanol,then $1 \mathrm{ml}$ of acetic anhydride was added followed by addition of concentrated $\mathrm{H}_{2} \mathrm{SO}_{4}$, a colour change from pink to violent was an indication of the presence of terpenoids [10]. 


\subsubsection{Test for Tannins}

The filtrate of the extract was boiled with 3 drops of $10 \%$ HCL and 1 drop of methanol added. A red precipitate was taken as evidence for the presence of tannins $[6,9]$.

\subsection{Acetic acid induced writing in mice:}

The Acetic acid induced writhing test in mice as described by [11] was employed. Twenty five (25) Swiss albino mice were divided into 5 groups of 5 mice each. The first group was given $10 \mathrm{ml} / \mathrm{kg}$ of Normal saline i.p. and served as control, groups 2 received Piroxicam 20mg/kg serve as a positive control, 34 and 5 received 50, 100 and $200 \mathrm{mg}$ of extract per $\mathrm{kg}$ of body weight i.p. respectively.. Thirty minutes later, mice in all the groups were treated with Acetic acid $(0.6 \% \mathrm{v} / \mathrm{v}, 1 \mathrm{ml}$ per $100 \mathrm{~g}$ body weight i.p.). Five minutes after Acetic acid injection, the mice were placed in individual cage and the number of abdominal contractions was counted for each mouse for a period of 10 mins. Percentage inhibition of writhing was calculated using the formula Inhibition $(\%)=$ Mean No of writhings(control)- Mean No. of writhings(test) $\quad$ x 100

Mean number of writhing (control)

\subsection{Anti-inflammatory Study:}

Increases in the rat hind paw diameter induced by subplanter injection of a phlogistic agent was used as the measure of acute inflammation[12] The phlogistic agent employed in this study was formalin $(50 \mu 1$ of $2.5 \%$ $\mathrm{v} / \mathrm{v})$.. The rats were randomly divided into five groups $(\mathrm{n}=5)$. Thirty minutes before the injection of formalin, the groups were treated i.p as follows group 1: normal saline $(10 \mathrm{ml} / \mathrm{kg}$ as a negative control), group $2(20 \mathrm{mg} / \mathrm{kg}$ of Diclofenac), groups 3, 4 and 5 received methanol leaves extract of Ocimum gratissimum at the doses of 50, 100 and $200 \mathrm{mg} / \mathrm{kg}$ respectively. Inflammation of the hind paw was induced by injecting formalin into the subplanter surface of the left hind paw. Paw diameter $(\mathrm{cm})$ was measured at 1, 2, 34 and 5 hours after formalin injection. Paw diameter after administration of the phlogistic agent was measured using vernier caliper.

Inhibition $(\%)=\underline{\text { Mean paw diameter (control) }- \text { Mean paw diameter (treated ) x } 100}$

Mean paw diameter (control)

\subsection{Statistical Analysis:}

Results were expressed as mean \pm Standard Error of Mean (SEM). The data was statistically analyzed using the one-way ANOVA. Results were statistically significant when $\mathrm{P}$ values are less than $0.05,0.01$ and $0.001(\mathrm{P}<0.05,0.01$ and 0.001$)$ as described by [13].

\subsection{Phytochemical Screening}

\section{Results}

The freshly prepared extracts were subjected to preliminary phytochemical screening test for various constituents. This revealed the presence of alkaloids, tannins, saponins, flavonoids, terpenoids and steroids.

\subsection{Acute toxicity study $\left(\mathrm{LD}_{50}\right)$}

The sign of toxicity were first noticed after 4-6 hours of extract administration. There was in decreased locomotor activity and decreased in sensitivity to touch and jerking. Also there was decreased in feed intake, tachypnoea and prostration after 10 hours of extract administration.

The median lethal dose $\left(\mathrm{LD}_{50}\right)$ in mice was calculated to be $1264.9 \mathrm{mg} / \mathrm{kg}$ body weight.(I.P)

\subsection{Anti-nociceptive study in mice}

TABLE 1: The extract demonstrated a significant $(\mathrm{P}<0.05)$ anti-nociceptive activity at all the doses $(50,100$ and $200 \mathrm{mg} / \mathrm{kg}$ body weight i.p ) tested compared to normal saline control. The activity resides more at the lowest dose $50 \mathrm{mg} / \mathrm{kg}$ body weight i.p that was found to have the highest percentage (75\%) inhibition of the abdominal constriction induced by acetic acid in mice.

\section{Anti-inflammatory study in rats}

TABLE 2: The extract was found to have a significant $(P<0.001)$ inhibitory effect on the formalininduced oedema in rats at all the doses $(50,100$, and $200 \mathrm{mg} / \mathrm{kg}$ body weight $i . p)$ tested in rats when compared to the normal saline control. 
Table 1: Effect of methanol leaves extract of Ocinum gratissinum given intraperitoneally on acetic acid-induced abdominal writhings contraction in mice

\begin{tabular}{lccc}
\hline Treatment (i.p.) & Dose (mg/kg) & $\begin{array}{l}\text { No. of abdominal } \\
\text { Contractions }\end{array}$ & \% inhibition \\
\hline Norma saline & 10 & $22.8 \pm 3.07$ & - \\
Piroxicam & 20 & $6.0 \pm 0.77^{\mathrm{c}}$ & 74 \\
Ocimum grassitimum & 50 & $5.5 \pm 1.19^{\mathrm{a}}$ & 66 \\
Ocimum grassitimum & 100 & $7.75 \pm 2.10^{\mathrm{b}}$ & 68 \\
Ocimum grassitimum & 200 & $7.4 \pm 2.25^{\mathrm{c}}$ & 75 \\
\hline
\end{tabular}

Values of abdominal contraction are mean \pm SEM. $n=5$

Values are statistically significant compared to control at $\mathrm{a}=\mathrm{p}<0.05$

Table 2. Effect of methanol leaves extract of Ocimum gratissimum on formalin -induced paw oedema in rats

\begin{tabular}{lllllll}
\hline Treatment & \multirow{2}{*}{$\begin{array}{l}\text { Dose } \\
\text { groups }\end{array}$} & \multicolumn{5}{c}{ Oedema diameter $(\mathrm{cm})$} \\
\cline { 3 - 6 }$(\mathrm{n}=5)$ & & & 2 hours & 3 hours & 4 hours & 5 hours \\
\hline Normal Saline & $10 \mathrm{ml} / \mathrm{kg}$ & $0.5660 \pm 0.21$ & $0.654 \pm 0.34$ & $0.6980 \pm 0.27$ & $0.7260 \pm 0.17$ & $0.806 \pm 0.23$ \\
Diclofenac & 20 & $0.620 \pm 0.20^{\mathrm{ns}}$ & $0.594 \pm 0.11^{\mathrm{ns}}$ & $0.612 \pm 0.08^{\mathrm{a}}$ & $0.630 \pm 0.26^{\mathrm{a}}$ & $0.640 \pm 0.24^{\mathrm{b}}$ \\
O.grassitimum & 50 & $0.612 \pm 0.30^{\mathrm{ns}}$ & $0.556 \pm 0.26^{\mathrm{c}}$ & $0.578 \pm 0.20^{\mathrm{c}}$ & $0.588 \pm 0.31^{\mathrm{c}}$ & $0.544 \pm 0.20^{\mathrm{c}}$ \\
O.grassitimum & 100 & $0.494 \pm 0.22^{\mathrm{ns}}$ & $0488 \pm 0.174^{\mathrm{b}}$ & $0.538 \pm 0.19^{\mathrm{a}}$ & $0.534 \pm 0.19^{\mathrm{a}}$ & $0.544 \pm 0.22^{\mathrm{c}}$ \\
O.grassitimum & 200 & $0.556 \pm 0.21^{\mathrm{ns}}$ & $0.548 \pm 0.26^{\mathrm{c}}$ & $0.618 \pm 0.35^{\mathrm{c}}$ & $0.640 \pm 0.23^{\mathrm{c}}$ & $0.6840 .39^{\mathrm{c}}$
\end{tabular}

Each value is mean \pm SEM of 5 rats

${ }^{\mathrm{a}} \mathrm{p}<0.05 ;{ }^{\mathrm{b}} \mathrm{p}<0.01 ;{ }^{\mathrm{c}} \mathrm{p}<0.001 \quad{ }_{\mathrm{a}}^{\mathrm{b}} \mathrm{c}$ : :statistically significant when compared to control ${ }^{\text {NS }}$ : statistically not significant when compared to control.

\section{Discussion}

The methanol leaves extract of Ocimum gratissimum was found to have shown a significant $(\mathrm{P}<0.05)$ anti-nociceptive effect at all the doses tested. Although, the inhibitory effect on the acetic-induced writhings in mice was not dose- dependent, the percentage inhibition at a dose of $50 \mathrm{mg} / \mathrm{kg}$ body weight of extract was found to be highest with $75 \%$ inhibition while that of the Diclofenac was $74 \%$. The abdominal constriction method is a very sensitive one and can detect anti-nociceptive effect of substances at a dose that cannot be detected by other methods, such as the tail- flick test [14] . Abdominal constriction responses were found to partly involve local peritoneal receptors [15]. The method has been associated with prostanoids in general e.g. increased levels of $\mathrm{PGE}_{2}$ and $\mathrm{PGEF}_{2} \alpha$ in peritoneal fluids [16] as well as lipoxygenase products by some researchers [17, 18]. Therefore, the results of the acetic acid-induced writhing strongly suggest that the mechanism of action of this extract may be linked partly to lipoxygenases and or cyclo-oxygenases. The activity demonstrated by the extract might be due to the presence of flavonoids and tannins that were present in the extract. This was supported by other workers who found that flavonoids and tannins were found to have antinociceptive and /or antiinflammatory activities [19].

The significant $(\mathrm{P}<0.001)$ anti-inflammatory activity exhibited by the extract at all the doses used $(50$, 100 , and $200 \mathrm{mg} / \mathrm{kg}$ body weight extract i.p.) against oedema induced by formalin in rats compared to the control group was an indication that the plant might serve as a useful source of anti-inflammatory agent. This anti-inflammatory effect of the extract observed might be due to the presence of flavonoid in the plant. This was supported by other workers, who found that flavonoids inhibit phosphodiesterases which are involved in cell activation, and their effect depends upon the biosynthesis of protein cytokines that mediate adhesion of circulating leucocytes to the sites of injuries [20].

\section{Conclusion}

The methanol leaves extract does possess significant $(\mathrm{P}<0.05)$ antinociceptive and anti-inflammatory effects in laboratory animals at the doses investigated. The results support the traditional use of this plant in some painful and inflammatory conditions and suggest the presence of biologically active components which may be worth further investigation and elucidation. 


\section{References}

[1] Iwu M (1993). Handbook of African Medicinal Plants. CRC press, BocaRatton, FL.

[2] Osito, N.G. (1992).A system of traditional health care. Vol .2. pp. 56-58

[3] Oliver, B. (1980).Medicinal plants in Nigeria. Published by Nigerian college of Arts, Science AND Technology. Ibadan, pp.90-94

[4] Sofowora,, L.A (1993).Medicinal plants and traditional Medicinal Medicine in African. Spectrum books Ltd, Ibadan. Pp. 55-71.

[5] Lorke, D. (1983). A New Approach to Practical Acute Toxicity Testing, Arch. Toxicol, 53: 275 - 287.

[6] Trease, G.E., Evans, M.C.(1989).Text book of Pharmacognosy $13^{\text {th }}$ Edition Bailiere Tindall, London, Toronto, Tokyo. Pgs. 200-201, 340-348, 419-423, 626-630, 765-775.

[7] Harbone, J.B. and Baxter, H,H. (1993). Phytochemical Dictionary. A hand Book of Bioactive Compound from plants. Taylor and Francis, Washington, D.C., U.S.A Pg 237.

[8] Markham, K.R. (1982).Techniques of Flavonoids Identification. Academic Press, New York, U.S.A. pp, 1-113.

[9] Vishnoi, N.R. (1989). Advanced Practical Chemistry.Yikas Publication House, PVT Ltd, Ghaziabad India. Pp.447-449.

[10] Silver, L.G.,Lee, I.S.,Kinghorn, D.A (1998).Special problems with the extraction of plants.In: Natural products Isolation ( Cannel. R.J.P.Ed) Humana Press Inc. 999, Riverview Drive,Suite 208, Totowa, New Jersey, U.S.A. 072512. pp. 343-364.

[11] Koster, R., Anderson, M. and Debeer, E.J.(1959).Acetic acid analgesic screening. Fed.Proc. 18:412-417.

[12] Winter, E. A. Risley, E.A., Nuss, G. V. (1963).Anti-Inflammatory and anti-pyretic activities of indomethacin. Journal of pharmacology and Experimental Therapeutics. 141,369 - 376

[13] Duncan, R. C; Knapp, R. G and Miller, M. C(1977).Test of Hypotheses in population Means, In: Introductory Biostatistics for Health Sciences, John Wiley and Son, Inc. N. Y. pp. $71-76$

[14] Collier, H. O. J; Dinneen, L. G; Johnson, C. A. and Schneider, C( 1968).The Abdominal constriction response and its suppression ion by analgesic drugs in the mouse, Brit. J. Pharmacol; 32: 295 - 310.

[15] Bentley, G. A. Newton, S. H. and Starr, J.(1981). Evidence for an action of morphine and the enkephallins can Sensory nerve endings in the mouse peritoneum,Brit. J. Pharmacol, 79: 125 - 134

[16] Levini, J.D., Lau, W., Kwait, G., Goetzl E.J. (1984).Leukotriene B $_{4}$ produces hyperalgesia that is dependent on the polymorphonuclear leucocytes. Science 255: 743-745.

[17] Derardt, R., Jougney, S., Delevalcee, F., Falhourt, M.( 1980).Release of prostaglandins E and F in an analgenic reaction and its inhibition. European Journal of Pharmacology 51:17 -24

[18] Dhara, A.K., Suba, V., Sen, T., Pal, S., Nag Chaudhuri, A.K.(2000). Preliminary studies on the anti-inflammatory and analgesic activity of the methanolic fraction of the root extract of Tragia involucrate. J Ethanopharmacology 72:265-268.

[19] Ahmadiani, A., Fereidoni, M., Semnanian, S., Kamalinejad, M., Saremi, S.(1998). Anti- nociceptive and anti- inflammatory effects of Sambucus ebulus rhizome extract in rats. J. Ethanopharmacology 61:229-235.

[20] Duke, J.A.(1992).Handbook of Biologically Active Phytochemcials and their activities. CRC Press, Boca Raton, FL, pp. 22 - 25. 